\title{
Criminal Proceedings Law Improvements for Justice Witnesses in Albania
}

\author{
Rezana Balla \\ $\mathrm{PhD}$, Lecturer, Marin Barleti University, Criminal \\ Law Department Faculty of Law, Tirana, Albania
}

\section{Abstract}

In the framework of the constitutional ${ }^{1}$ justice reform $^{2}$ of year 2016, "Constitutional reform in Albania of year 2016 determined fundamental amendments by improving justice system." (Balla, 2017, p. 368), there are undertaken to be improved important justice laws. Therefore, fundamental amendments are made on the Criminal Proceedings Code (CPC) on year 20173. These amendments consisted in general and specially to enable the implementation of government policy, for the establishment of new institutions and the strengthening of existing ones, in the fight against corruption and the consolidation of the justice system. At the same time, the amendments aim to address the most obvious issues and problems encountered in practice. Correspondingly, the constitutional amendments and the adoption of other laws, necessary to implement them, brought the need to unify and harmonize these amendments in the CPC. In particular, the new regulations aim to determine the prosecutor's independence in the criminal proceedings, the establishment of the Special Prosecution Office, the jurisdiction of the High Court and the change in the subject matter jurisdiction of the Court of Corruption and Organized Crime. Through this paper it is addressed the treatment of new standards and institutes that are regulated in the CPC. How do they stand compared to European standards such as the jurisprudence of the ECtHR and international law, as well as the jurisprudence of International Criminal Court (ICC). The paper aims to address issues related to the rights of defendants, the legal position of the victims and

${ }^{1}$ Constitutional Law Amendments (2016) published on Official Journal year 2016.

2 Balla, R. (2017). Constitutional Reform, Criminal Justice Reform on Prevention of Organized Crime and Corruption, Proceedings of International Scientific Conference at Faculty of Law, Tirana University, Albania. p. 368.

${ }^{3}$ Amendments to the Criminal Proceedings Code CPC have been adopted by law no. 36 dated 30.03.2017. https://alblegis.com/Legjislacioni/Ligji-Nr.36-Dt.-30.03.2017-Kodi-Penal-i-ndryshuar.pdf, (March 16 th 2020). 
especially the treatment of the most favorable legal status of protected witnesses ${ }^{1}$ and collaborators of justice.

Keywords: justice witnesses, collaborators of justice, the rights of defendants, victims of crime, criminal proceedings.

\section{Introduction}

The new amendments to the CPC have been proposed by the Ministry of Justice ${ }^{2}$, according to the process of drafting and reviewing a proceeding that has lasted more than a year. EURALIUS ${ }^{3}$ has contributed on providing legal assistance. CPC is also included in the Criminal Justice package within the Justice Reform. In particular, it is important to mention the change in the jurisdiction of the High Court, which led to the reformulation of the provisions on the limits of review of this court and the transfer of other powers, such as requests for review, or trial of officials of other courts etc. One of the most important issue is the establishment of the decentralization of the prosecution institution. This decentralization is accompanied by determining the role and functioning of the pretrial judge to guarantee the control of the prosecution activity and proceedings during investigation procedure. The other important issue is the establishment for the first time in the justice system in Albania of the special Court on Corruption and Organized Crime.

Based, directly on the analytical document of the justice system and the national strategy for justice reform, as well as judiciary decisions so far, it is determined the need for amendments of some e institutes of CPC, aiming at its approximation with the best European standards and the best international ones foreseen by international instruments ratified by the Republic of Albania and the ones aiming to adhere, such as: European Convention on Human Rights (ECHR), standards established by European jurisprudence for Human Rights and Justice Court (ECtHR), the Acquis Communautaire of the European Union, the Convention on the Protection of the Rights of the Children, etc.

Amendments of the $\mathrm{CPC}$ represents the recently constitutional amendments based on the point of view of the normative acts, and in the same time they represent harmonization with other approved laws, in the framework of the Justice Reform at the criminal field such as: the Law on the Organization ${ }^{4}$ and Functioning of

\footnotetext{
1 Balla, R.. (2007). Witness and Justice Collaborators Protection. The Journal "E Drejta Parlamentare dhe Politikat Ligjore”'“. Tirane, Albania. No 39, p.17-57.

2 Information is published at Ministry of Justice web page http://www.drejtesia.gov.al/njoftime-teministrise-se-drejtesise/ (March 16 th 2020).

6 EURALIUS is an EU funded project. The project is implemented by a Consortium composed of the German Foundation for International Legal Cooperation (IRZ) as Lead Partner.
}

${ }^{4}$ Law No. 97/2016 “On Organization and Functioning of Prosecution in the Republic of Albania”, published on Official Journal no. 209, year 2016, p. 22305. 
Prosecutions, the Law on Organization and Functioning of Institutions to Fight Corruption and Organized Crime ${ }^{1}$, draft law on juvenile Code, and other draft law of the legal package discussed and agreed to be changed at the High Level of Experts Group. These amendments of the provisions are intended, inter alia: to present the concept of the victim as an important subject in the criminal proceedings; to guarantee the protection of the human rights of juveniles by regulating in a special manner every court proceedings related to juveniles; expanding the rights and protection of the of the defendants in the criminal proceedings in compliance with the best international ${ }^{2}$ standards, introducing for the first time into the criminal justice system the concept of the letter of rights, to guarantee the testimony of protected witnesses or with a hidden identities, etc.

Inter alia the amendments indent to regulate the reinforcement of the role and position of the prosecutor ${ }^{3}$ on directing, controlling, and conducting preliminary investigations. Guaranteeing procedural instruments and reasonable deadlines for conducting investigative actions, in accordance with the complexity of the court case. Conducting uninterruptedly trial. Increasing the authority of the court in the normal discipline and development of criminal proceedings. Involvement of new types of special trials that influence the reasonable time for judgment of simple issues and help the investigation, such as the criminal order of condemnation and judgment by agreement. Regulation of special current trials. Forecasting the necessary legal mechanisms that enable the participation of the defendant and / or his defense counsel in the trial to avoid trial in absentia. Improving the arrangements for notifying the parties in the criminal proceedings. Improvements of appeals that will impact the process of trial and will decrease the court cases at Appeal Courts. Review of the powers of the High Supreme Court in the criminal process after the constitutional amendments.

\section{Legal provision of defendants, collaborators of justice and victims}

\section{II.1- Defendant's Rights}

At the general provisions section, of the CPC the amendments consist to the principles of the criminal process by reflecting the accepted international standards and the jurisprudence of the European courts. Article 2 is amended by adding paragraph 2 with the main objective to implement the provisions of the juvenile Code. It is determined that the verdict of guilty will be given only in cases of its probationary, beyond any reasonable doubt, based on the common law ${ }^{4}$ standard, which is further identified and elaborated by the ECtHR, in all its jurisprudence, which is also accepted

\footnotetext{
${ }^{1}$ Law on Organization and Functioning of Institutions to Fight Corruption and Organized Crime published on Official Journal no. 209, year 2016.

2 Damaska, M. (1975). Structures of Authority and Comparative Criminal Procedure. Yale Law Journal, 84, p. 480-544.

3 Vogler, R.. \& Ashgate, K.. ( 2005). A World View of Criminal Justice, London, England. p 27-140.

${ }^{4}$ Cassese, A. (2003) International Criminal Law, Oxford University Press England. p. 52-107.
} 
and applied by the domestic courts of almost all European Union countries. This principle guarantees the observance of the principle of the presumption of innocence and the charge of the accusation with the burden of proof in the criminal ${ }^{1}$ proceedings. This principle is foreseen at Article 4 point 2.

This article is improved with the aim to be in accordance and harmony with article 30 of the Constitution. The implementation of this principle is depended directly on the judiciary system on how they understand and apply it, that will be the main warranty that the rights of the defendant will be protected during the whole criminal proceedings from the investigations to the trial. The principle of presumption of innocence ${ }^{2}$ releases the defendant from the burden of proving his innocence, gives him the right not to respond to accusations and not to be responsible for the statements performed. The first paragraph of this article symbolizes the presumption of innocence principle. This presumption is already part of the constitutional presumptions, as well as part of Article 6, paragraph 2, of the ECHR. This presumption must be respected before the trial, during the trial, and even in case the defendant pleads not guilty. The statement is elaborated clearly based on the ECtHR's Decision Minelli ${ }^{3}$ vs Switzerland 25.3.1983.

With regard to this universal principle, the proposal is based on the Directive ${ }^{4}$ of the European Parliament and of the Council (2013) 821 "On the strengthening of certain aspects of the presumption of innocence and the right to be present at a trial in criminal proceedings". In accordance with its Article 5 "The burden of proof and the standard of proof are required", paragraph 3 provides as follows: Member States must guarantee that in cases where the court makes a judgment on the guilty of a suspect or accused person and if there is a reasonable suspicion of the guilt of the defendant then this must be considered in favor of the defendant and he should be released as not guilty.

The standard of presumption of innocence principle has been developed over the years. The ECHR sets out this principle in Article 6 (2). The ECHR provides for three key requirements: the right not to be publicly presented as convicted by public authorities prior to the final decision. The fact that the burden of proof is on the public accusation. In Albania, the accusation is represented by the prosecutor and the accused benefits and has the right to be informed about the accusation of any reasonable suspicion of his guilt. The ECtHR also acknowledges the existence of a clear relation between the presumption of innocence and other rights related to a fair

\footnotetext{
1 Vogler, R.. \& Ashgate, K.. (2005) A World View of Criminal Justice, London, England. p. 20-30.

2 Palazzo, P \& Giappichelli. ( 2000) Lezioni di diritto penale comparato Torino, Italy. p.220-270.

3 ECHR's Decision, Mineli vs ZSwitzerland 25.3.1983;

https://hudoc.echr.coe.int/eng\#\{\%22itemid\%22:[\%22001-57540\%22]\}; visited on (March 19th .2020).

4 Directive of the European Parliament and of the Council (2013) 821 "On the strengthening of certain aspects of the presumption of innocence and the right to be present at a trial in criminal proceedings".
} 
trial, in the sense that when such rights are violated, the presumption of innocence is inevitably at risk.

The right not to be incriminated ${ }^{1}$, the right not to cooperate and the right to remain silent and the right to liberty (and not to be held in custody before trial). The ECtHR ruled that one of the basic aspects of the principle of presumption of innocence is the fact that a court or public official may not publicly present the suspect or accused as guilty of an offense if it is not proven and they are not found guilty, by means of a final decision. Furthermore, such a decision must be implemented by all public authorities. Both situations may encourage the public to believe that the person is guilty and to prejudge the assessment of the facts by the judicial authority.

The second paragraph amended represents the principle in dubio pro reo. The provision represents a reason as well for innocence. This means that the judge finds not guilty, not only when there is no convincing evidence for the defendants, but also in cases where there is insufficient evidence. From this point of view, it is important to note the above-mentioned amendment, in relation to the arguments set out in Article 4 in which is determined that "The burden of proof and the standard of proof are required." This provision stipulates that: The presumption of innocence presupposes that the burden of proof remain on the prosecutor ${ }^{2}$ and the suspect or accused must benefit from any suspicion of guilt (in dubio pro reo). The presumption of innocence presupposes that the burden of proof is on the prosecutor and the suspect or accused must benefit from any suspicion of guilt (in dubio pro reo). This presupposes that a court's decision should be based on the data presented before it and not simply on statements or assumptions. This fact is very important for our paper because this is one of the fundamental justice principles. Therefor the value of the protected witness is precious if the testimony will be performed in harmony with this principle, the administration of justice and the fair trial of the defendant would be ensured on the basis of the basic evidence of the protected witness. This remains without prejudice to the independence of the judiciary when judging the guilt of the suspect or the accused.

Furthermore, the ECtHR has acknowledged that in specific and limited cases the burden of proof may shift to defense. This guideline does not prejudice the possibilities of defense to present data in accordance with applicable national rules. It is determined the recognition of the principle of freedom of evidence and the obligation of the prosecution to gather both evidence in its favor and those in favor of defense, by reflecting the obligation of the prosecution to uncover the truth.

\footnotetext{
${ }^{1}$ Frase, Richard, S. (1995) German Criminal Justice as a Guide to American Law Reform, Weigend,: Similar Problems, Better Solutions?" USA, Boston College International and Comparative Law Review, 18. p. 317-360.

2 Pradel, J. \& Cortens, G. \& Vermeulen, G. \& Papialis, (2009). European Criminal Law. Tirane, Albania. p. 224-251.
} 
It is determined as well the recognition of this obligation that avoids any arbitrary conduct of the prosecutor or the judicial police during the investigation by avoiding evidence in favor of the defense, by charging the prosecutor with disciplinary responsibility, according to the relevant law (Article 8/a).

The amendments are defining the principle of non-punishment twice for the same criminal offense (ne bis in idem principle), by reflecting the constitutional definition, as well as the standard accepted by domestic and international case law on the application of this principle, not only in cases where the person has been convicted previously for the same criminal offense, but when the criminal fact has been previously tried (Article 7). Explicitly, the principle ne bis in idem prohibits a defendant from being tried again after discharging guilt or innocence verdict. This principle is enshrined in many international instruments, including the European Union Schengen ${ }^{1}$ Convention on 1990 and the Seventh Protocol of the ECHR. The ECtHR at its court case the Zolotukhin ${ }^{2}$ vs Russia, App. No. 14929/03, has determined that if a criminal proceeding is initiating from facts, which are identical or essentially the same as the first criminal trial, notwithstanding the charge, the second proceeding must not begin.

Regarding the amendments of the provisions for the defendant. They include reformulating of the current provisions and improving them, there have also been new provisions articulated for the first time, in all these years of post-communism, and in Albanian jurisprudence, by reflecting in the best way the European and international standards on the rights of the defendant. Hence, are determined the rights of the defendant to be informed with the accusation against him and the rights in criminal proceedings if he has the position of the person against whom the investigations are being conducted. For this purpose, it is foreseen reformulation of Article 34/a, in where are stipulated the rights of the person under investigation. The way of informing him with the rights in the criminal proceedings, before starting the interrogation by notifying the "letter of rights". This is one of the newest processes installed in CPC that has never happened in criminal proceedings for the defendant to be notified with the rights and to sign on to become aware of these rights. Despite the constitutional rights that everyone must be informed for the accusation against him. The provisions and the process in general are considered among the most democratic and progressive standards because recognition of the rights will help the defendant to provide better protection throughout his criminal proceedings.

\footnotetext{
1 European Union Schengen Convention of year $1990 \mathrm{https}$ //eur-lex.europa.eu/legal content/EN/TXT/?uri=CELEX\%3A42000A0922\%2802\%29, (March 16 ${ }^{\text {th }} 2020$ ).

2 Sergey Zolotukhin v. Russia - HUDOC - Council of Europe hudoc.echr.coe.int > app > conversion > pdf; (March 16 ${ }^{\text {th }}$ 2020)..
} 
Specifically, in paragraph 1 of the Article 8, the rights of the defendant are defined in compliance with the Directive 2012-13-EU1 on the right to information in criminal proceedings, with the Directive 2013-48-EU² on the right of access to a defense counsel in criminal proceedings and with the Directive 2010-64-EU ${ }^{3}$ on the right to translation in criminal proceedings, as well as the Resolution ${ }^{4}$ of the Council on Procedure for the Enforcement of Procedural Rights of Suspected or Accused Persons in Criminal Proceedings and the ECHR Convention, and the ECtHR's decisions.

The first right determined to the defendant in letter a) of the first paragraph of this article provides for his right to be informed as soon as possible about the charges against him, in the language in which he understands. This right given by the abovementioned EU Directives is based on the rights granted by Article 6 of the ECHR. This right is derived from many ECtHR's decisions such as the Abramyan v. Russia $10709 / 02^{5}$. Based on this decision the Court draws attention to the fact that the provisions of paragraph 3 (a) of Article 6 of the Convention indicate the need for special care to be given to the notification of the 'charge' to the defendant. The details of the criminal offense play an important role in the criminal process, which means that from the moment of delivery the suspect is considered to have been notified in writing of the factual and legal basis of the accusation against him. The Court further recalls that the object of Article 6 (3) (a) must be assessed in particular in the light of the broader right to be heard regularly guaranteed by Article 6 (1) of the ECHR. In criminal cases, providing full and detailed information about the charges against a defendant and consequently the legal qualification that the court may apply to the case is an essential precondition for ensuring that the trial is fair, see Pelissier and Sassi v. France, no. 25444/94 § 52, ECtHR 1999-116; France, no. 25444/94 § 52,

\footnotetext{
${ }^{1}$ Directive 2012-13-EU, on the right to information in criminal proceedings published on European official journal https://eur-lex.europa.eu/legal-content/EN/TXT/?uri=celex:32012L0013, (March 20 th 2020).

2 Directive 2013-48- EU on the right of access to a defense counsel in criminal proceedings published on European official journal https://eur-lex.europa.eu/legal-

content/EN/TXT/?uri=celex\%3A32013L0048, (March 20 th 2020).

3 Directive 2010-64-EU, on the right to translation in criminal proceedings published on European official journal https://eur-

lex.europa.eu/LexUriServ/LexUriServ.do?uri=0J:L:2010:280:0001:0007:en:PDF (March 20th 2020).

${ }^{4}$ Resolution of the Council on Procedure for the Enforcement of Procedural Rights of Suspected or Accused Persons in Criminal Proceedings published on European official journal https://eurlex.europa.eu/legal content/EN/TXT/?uri=uriserv:OJ.C_.2009.295.01.0001.01.ENG\&toc=OJ, (March

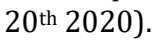

5 ECtHR's Decision ABRAMYAN v. RUSSIA 10709/02 published on European official journal https://hudoc.echr.coe.int/fre\#\{\%22itemid\%22:[\%22001-155161\%22]\}, (March 20th 2020). ${ }^{6}$ ECtHR's Decision Pelissier dhe Sassi v. France, no. 25444/94 § 52, ECHR 1999-11, published on European official journal https://hudoc.echr.coe.int/eng\#\{\%22itemid\%22:[\%22001-58226\%22]\}, (March 20th 2020).
} 
ECtHR 1999-111; Mattocia v. Italy, no. 23989/94, § 58, ECtHR 2000-IX2; Ollinger vs Austria, nr. 42780/98 § 34, 20 April 20063.

According to letter $\mathrm{h}$ ) of article 34 are provided to the defendant other rights foreseen at the CPC such as the right to sign a decision under the agreement or to enter into a cooperation agreement or to file an appeal against the court decision, etc.

The second paragraph of this article provides for the defendant's right to receive a written letter on his rights. "The Letter of Rights" it is provided on written to the defendant and its content is in compliance with the provisions foreseen by the EU Directive 2012/13. This Directive contains the model for the letter of written rights. This fact is implemented for the first time in the history of the rights of the defendant in the years of democracy in Albania. It is very important for the defendant that before his first interrogation he is aware of the rights, to better exercise his protection.

Following the guarantees of the defendant, Article 34/b was proposed, as a new article, so for the first time we have a new, special provision in the CPC where the special rights of the defendant are provided. The rights of the arrested or detained person to be informed of the reasons for the arrest or detention provided for in letter a) of this article is the right provided by Directive 2012/13/EU and is in accordance with the established standard from Directive 2010/64/EU. The right of access to a lawyer is guaranteed to a detained or arrested person, to meet privately and to communicate with him before being questioned by the police or the judicial authority. The right of the defendant to communicate with the defense counsel, away from a third party, is part of the basic requirements of a fair trial in a democratic society and is derived from Article $6 \S 3$ (c) of the ECHR.

Correspondingly, the role of the defendant as a witness is foreseen, in cases when he is a collaborator of justice, by charging him with criminal responsibility in case of false declaration. Of particular importance for our study is the fact that for the first time in the history of Albanian jurisprudence, the case of the collaborator of justice, his responsibility and benefit has been regulated in detail, avoiding the problems encountered by practice (Articles 36/a, 37, 37/a and 37/b). For the first time it is stipulated a reformulating article at CPC by determining that the collaborator of justice can give the testimony as a protected witness. According to the new amendments a defendant can gain the status of collaborator of justice by singing the collaboration agreement with the prosecutor. The most important fact is that the agreement can be signed at any stage of the criminal proceedings even after the final decision. The collaborator of justice can have special protection for himself and his

\footnotetext{
${ }^{1}$ ECtHR's Decision published on European Court website https://hudoc.echr.coe.int/eng\#\{\%22itemid\%22:[\%22001-58226\%22]\}, (March 20th 2020). 2 ECtHR's Decision Mattocia v. Italy, no. 23989/94, § 58, ECHR 2000-IX, published on European Court website https://hudoc.echr.coe.int/eng\# $\{\% 22$ itemid\%22:[\%22001-58764\%22]\}, (March 20 th 2020). 3 ECtHR's Decision Ollinger v Austria, no. 42780/98 § 34, 20 Prill 2006, published on European Court website https://hudoc.echr.coe.int/eng\# \{\%22itemid\%22:[\%22001-76098\%22]\}, (March 20 th 2020).
} 
family. The content of the agreement must clearly stipulate the testimony that will be crucial for the court proceedings.

\section{II.2- Testimony}

Article 158, paragraph 3, is added, which provides for the prohibition of exclusion from evidence, in cases of criminal offenses against minors. It is similarly, provided for the first time in the provisions of criminal procedure, in accordance with the recommendations of European standards and especially those of ECtHR, paragraph 6 in Article 160 on the manner of obtaining evidence of infiltrated persons which is done by keeping and maintaining hidden their identity.

The provisions for obtaining the testimony of a protected witness have been presented for the first time ${ }^{1}$ in the CPC, as very clear and complete for the testimony of an anonymous witness, or a witness with a hidden identity. This provision is provided for each witness, even for those who have not entered, in the witness protection program. The provisions of Article 165/a, aim to regulate the cases of anonymous witnesses, providing for the cases and procedure followed for situations when the witness or a relative of his may be in serious danger to their life or health, due to their testimony.

Correspondingly, criminal offenses are provided, in the trials of which this evidence will be accepted with a hidden identity. According to the ECtHR recommendations, the rights and freedoms of the defendant should be limited to ensure that the testimony is given in a process in which the witness feels threatened and seriously threatened for the life and health of himself and his relatives. This provision is progressive and is provided as well for witnesses who are not part of the witness protection program and will guarantee the implementation of justice. Taking into consideration that many criminal processes failed just because witnesses ${ }^{2}$ withdrew from testifying because they felt threatened and thus the entire trial failed.

At point 3 of article 165/a it is foreseen that the closed envelope containing the full identity of the anonymous witness is handed over by the prosecutor to the head of the trial panel and only he can be aware of full identity of witness protected. However, according to the ECtHR's recommendations explained in the chapters above, the trial panel cannot be informed of the identity of the protected witness, because there is

\footnotetext{
${ }^{1}$ Islami, H. \& Hoxha, A. \& Panda, I. (2006) Proceedings Law. Morava, Tirane, Albania. p. 213-328.

2 Serious Crime Court's Decision no. 16, date 20.03.2007., http://www.gjykata.gov.al/apel-krimet-er\%C3\%ABnda/gjykata-e-apelit-krimet-e-r\%C3\%ABnda/ (April 2017). As per this decision the witness a juvenile girl was called to testify at the court session in front of two adults that were accusing for sextual exploitation and international trafficking with human being the witness in this court case was victim of the defendants' crime. Therefore, the witness felt threatened and she changed the testimony. Previously during investigations, she was interrogated by the prosecutor and she confirmed that the defendants were the persons who exploited her, but she changed the testimony at the court by saying that she does not know the defendants. The same mistake was made even by the Serious Crime Appeal Court so definitely two defendants were declared as not guilty by the court.
} 
always possibility of leaking information. After all, here in Albania, the court of serious crimes has shown that it has been unable to preserve the identity of the protected witness. There have been many criminal cases where the information on witness identity has been disclosed ${ }^{1}$ before the trial taking place. In order to preserve the identity of the witness, another judge, who does not adjudicate the case, must verify it and the trial panel must not have any information on the identity of the witness. Only, in this way can be concealed the identity of the witness and he can be saved from the threats to his life and the health of himself and his relatives. Also, the prosecutor's request for the testimony of a witness with a hidden identity must be examined by another judge and only he can be notified for his identity. In this way, the trial panel that examines the criminal case will be informed for the decision taken by the single judge and will continue to implement the decision taken and proceed by having the testimony of the witness with a hidden identity. This recommendation is implemented as well by the ICC when having testimony of the witness protected on the criminal proceedings. Only in this way is it emphasized that in a series of decisions of the ECtHR, a reasonable and fair judicial process can take place and justice can be done, put in order.

Although, in point 6 of article 165/a it is determined that the court if it approves the request of the prosecutor decides the pseudonym of the witness and the procedures of concealment of identity and the interrogation is done according to the conditions provided in article $361 / \mathrm{b}$ of the CPC which we will analyze below, again we think that this provision should be reformulated. According to the ECtHR, no decision should be taken that could lead to the identification of a protected witness. Therefore, the witness must be provided with first and last name, that is, with new generalities and not with a pseudonym, as this way his identity can be suspected or exposed.

Accordingly, the provision of this article "witness with a hidden identity" is defined at the general rules of the CPC and it is not given any opportunity to know, if all these actions, for example the submission of the prosecutor's request to receive evidence from the witness with the hidden identity, the examination of the request by the head of the trial panel and then the appeal that the prosecutor may proceed for the court decision, all these procedures will be undertaken in the presence of the defendant or not. This is not clearly determined in this provision. If the defendant will be notified on these procedures, then everything will be ruined. The defendant can not have information on personal history of the witness otherwise his identity would be exposed. One of the certain guarantees of the ECtHR is that defendants should be restricted in their rights. The defendant must have no information on the identity of the witness. If not, all these criminal proceedings taken for the witness protection process would not function to the purpose for which they are drafted and

\footnotetext{
1 https://gazetamapo.al/deshmitaret-e-mbrojtur-qe-nuk-mbrohen-por-dekonspirohen/ (April, 2015) Refering the media during the court session when the court called for testifing the witness with hidden identety the defendant disclosed the real identity of the witness. The prosecutor was surprised on how the defendant knows the identity of the protected witness. .
} 
implemented. We therefore consider it important to determine that it is prohibited for the defendant and his defense counsel to be notified with the request of the prosecutor and not to participate in the examination of the decision to conceal the identity of the witness. Because only in this way can the identity of the witness be hidden and preserved, and his life and the lives of his relatives can be protected.

Another positive provision is the definition of Article 169 on confrontation. It stipulates in the second paragraph that it is prohibited to confront the adult defendant with the victim or the juvenile witness, to guarantee the protection of the juvenile and the victim. Based on the decision of the court of serious crimes which confronts the victim of the trafficking in human beings crime whom was a minor and she felt scared at trial and she changed the testimony by declaring that she does not know the adult defendant whom had been her smuggler and had persecuted by sextually exploitation. Similarly, the Court of Appeals for Serious Crimes makes the same mistake and in this way the defendant trafficker was declared guiltless of the crime of international trafficking in human beings with minors.

The amendments to the CPC have also aimed to regulate the manner in which witnesses are questioned by setting for the first time, in accordance with international standards of law, the prohibition of questions affecting the witness's impartiality and also the prohibition of suggestive questions aimed at suggesting responses.

The amendments to Articles 361/a and 361/b have provided for special cases and procedures to be followed for obtaining the testimony of a minor, a provision in accordance with the Juvenile Code. The amendments of Article 361/b have reinforced the application of special techniques for interrogating collaborators of justice, infiltrated persons and/or persons under cover, and protected witnesses and witnesses with hidden identities. These techniques enable the development of longdistance court hearings, through audiovisual means. An important issue for this paper is precisely the implementation of the ECtHR recommendations for obtaining testimony from witnesses with hidden identities.

In these cases, the ECtHR stipulates that the court must take appropriate measures to ensure that the defendant's face and voice are not identified and encrypted by the parties. This regulation is provided for in point 2, first paragraph of Article 361/b. But the second paragraph of point 2 provides that the court orders the summoning of a witness if it is necessary to recognize and supervise the witness. This regulation absolutely is not in harmony with recommendations of the ECtHR and with the articles explained above on encrypted the face and voice of the witness. If the witness will be notified by the court, then the witness identity will be disclosed and the whole efforts for protecting the witness will be damaged. Disclosing the identity of a protected witness with a hidden identity may not be necessary in any case, as there is a very strong reason why the decision was made to protect the witness, such as threatening his life or the lives of his relatives. If the identity of the protected 
witnesses or anonymous witnesses is revealed ${ }^{1}$, even by the court, this would destroy the entire mechanism that has been set up to protect the witnesses.

Approximately, the identities of 40 percent of those witnesses who collaborated with the International Criminal Tribunal for the former Yugoslavia (ICTY) ${ }^{2}$ have been kept secret because of the security of their lives, according to the court's closing report. However, witnesses again faced threats. As a result, it would not be wrong to say that those who testify in the local courts will face far greater pressures and threats. If these protected witnesses will be disclosed their identities, then their lives will be in danger and the process may fail to deliver justice, especially in the case of witnesses whose testimony is crucial to the criminal process. Therefore, it is suggested to be revised the second paragraph mentioned by insuring stronger protection to the witnesses. Furthermore, paragraph 3 of the article provides that the court may not allow questions to be asked which may disclose the identity of the witness.

We should welcome this provision as it is a new definition that has not been before, and it really aims to protect witnesses from intimidation and threats. But, based on the international practice of the ICC and the ECtHR, they also point to a number of recommendations that no questions should be allowed that may reveal personal stories or certain traits, or other features that would lead to witness disclosure. Therefore, we would recommend a clearer provision where it will be explicitly stated that no kind of question will be allowed regarding life, school, profession, work, all activities where the witness has participated during his life and such questions that may jeopardize the disclosure of his identity.

\section{II.3- Wiretapping}

The amendments to the CPC consist of reducing the sentence for criminal offenses from seven years to four years to the maximum for which wiretapping is allowed. The maximum of seven years, as previously predicted, was too high and wiretapping could not be allowed for the investigation of certain important and serious crimes, such as corruption, trafficking in human beings, crimes committed by organizations. criminal or structured groups, etc. The reduction of the maximum sentence to four years is in accordance with the meaning of serious crimes provided for in the Palermo Convention against Organized Crime and its two protocols, ratified by Albania under Law no. 8920, dated 11.7.2002, which provides in Article 2, letter b, that "Serious Crimes" constitutes a criminal offense punishable by imprisonment of a maximum of at least four years or a more severe punishment.

\footnotetext{
1 Xhafo, J. (2010). International Criminal Law. Tirane, Albania. p. 239-.249.

2 The report on the closure of the International Criminal Tribunal for the former Yugoslavia (ICTY) in the Closing of the Hague Tribunal, an International Criminal Tribunal for the former Yugoslavia in 1993, established by UN decision to try crimes in the former Yugoslavia, and the legacy it left behind. https://www.trt.net.tr/shqip/ballkani/2017/12/12/koment-tribunali-i-hages-dhe-trashegimia-qe-laprapa-866543 (April 3rd 2020).
} 
As mentioned above, in order to conduct a successful investigation and bring the offenders to justice, wiretapping, as one of the most important procedural actions, should be allowed for criminal offenses punishable by not less than four years in maximum. Predicting the involvement of wiretapping methods in crimes punishable by up to four years on the one hand will make it possible to fight these crimes more, given that these are criminal offenses such as corruption where the subjects of these offenses are subjects with high professional skills, such as that of corruption committed by senior officials and make it impossible to commit sophisticated offenses, leaving no trace, and no space for employees whom pursue criminal prosecution to detect them. But, on the other hand, the employees whom will perform the interceptions must be very careful and well trained in exercising this delicate function, as the interceptions constitute a violation of privacy, personal life of the individual, especially in the investigation phase as there is only suspicion against persons, for committing a criminal offense and we are not sure whether we should infringe on the interests that have been established to protect privacy. In these cases, must be clearly defined and balanced to understand what are the prevailing interests, the protection of privacy or the public interest, to fight against the crime and therefore must be balanced to fairly evaluate which will be the interests that will prevail. In some court cases of serious crimes, has resulted that only wiretapping material has incorrectly incriminated persons who have nothing to do with criminal activity, and this constitutes a major violation of human rights. For these reasons, the reduction of the sentence, will increase the range of criminal offenses that will lead to a burden on employees and can certainly lead to the violation of human rights and freedoms. The reduction of the sentence of criminal offences at no lower than four year is in compliance with other laws as well, especially the witness protection law. According to this law at article 2 it is foreseen that: "disposition of this law will apply for criminal offences that it is foreseen a sentence not lower than four year". Letter b) of paragraph 1 of this article of CPC has been amended in order to allow this instrument to be used in the event that the criminal offense was committed intentionally, by means of telecommunications or the use of information technology or computer technology. Whereas, the procedural interception is foreseen in the above articles, the procedures, authorities and reasons based on which the preventive interception takes place in the Republic of Albania are foreseen in the Special Law no. 9157, dated 4.12.2003, "On wiretapping of telecommunications".

Regarding the preventive interception, the judicial practice of the ECtHR states the following in the court case ruled by decision no. 4378/02 of Bykov ${ }^{1}$ vs Russia dated 10 March 2009. The Court has consistently considered that when it comes to intercepting communications for the purposes of a police investigation, the law should be clear enough, in the sense of giving citizens an appropriate indication of the circumstances and conditions in which public authorities are authorized to return to

\footnotetext{
1 Decision no. 4378/02 date March 10 th 2009, Bykov vs Russia published on European official journal https://hudoc.echr.coe.int/fre\#\{\%22itemid\%22:[\%22001-91704\%22]\}, (April 1st 2020).
} 
this covert and potentially dangerous interference with the rights to privacy and correspondence. In the Court's view, these principles apply equally to the use of a radio broadcasting device, which, in terms of the nature and extent of the relevant intervention, is virtually the same as telephone tapping.

\section{II.4- Victims}

According to Directive 2012/29/EU1 which replaced the Framework Decision of the Council 2001/220/ the victims, should have the right to testify in their own language. The third paragraph of this article provides for the right of the defendant and the participants in the trial to be informed, if necessary, through an interpreter, regarding the evidence obtained. The last paragraph ensures that costs related to the translation and interpretation of sign language must be covered by the state in accordance with European and international standards. The amendments to the CPC have introduced the obligation of the victim to participate as a party in the criminal proceedings, by guaranteeing its access to the criminal proceedings, in accordance to the determination of the EU Framework Decision on the status of victims in criminal proceedings dated 15/03/2001 Article 9/a.

The amendments of the CPC provide for significant changes for the victim and the accused victim. Thus, the provisions on the victim and the accusing victim are considered very progressive and have provided for the replacement of the role of the "victim of the criminal offense" with the term "victim". Regarding the term used, a great and valuable replacement has been made, because according to the previous provision of the Code, by labeling it with the term "Damaged", an object is conceived, something that has been damaged and not a human being, a victim of a crime, an innocent victim and subject to criminal activity that have been violated, not only on material but moral damage as well as its fundamental rights and freedoms.

At the same time, the term "damaged accusing" with the term "indictment victim", giving the relevant definitions and regulations for these terms in accordance with the Framework Decision of the Council of Europe ${ }^{2}$ of 15 March 2001 on the Victims' Attitude in Criminal Procedure and the Directive 2012/29 / EU ${ }^{3}$ which has replaced this decision.

\footnotetext{
1 Directive 2012/29 of the EU and the Council on October 2012 To set minimum standards for the rights, support and protection of victims of crime, which replaced the Council Framework Decision 2001/220 https://eur-lex.europa.eu/legal-content/en/TXT/?uri=CELEX\%3A32012L0029, (April 2 ${ }^{\text {nd }}$ 2020).

2 Framework Decision of the Council of Europe of 15 March 2001 on the Victims' Attitude in Criminal Procedure published on the European Official Journal http://data.europa.eu/eli/dec_framë/2001/220/oj, (March 30th 2020).

${ }^{3}$ Directive 2012/29/EU Council of Europe October 2012 For the Determination of the Minimum Standards of Rights, Support and Protection of Victims of Crime, which replaced the Framework Decision of the Council Directive 2001/220/JHA published in the Official Journal https://eurex.europa.eu/search.html?qid=1585598884134\&text=Directive\%202012/29\%20/EU\&sco pe=EURLEX\&type $=$ quick\&lang $=$ en $\left(\right.$ March $\left.20^{\text {th }} 2020\right)$.
} 
For this reason, Article 58 of the CPC has been completely reformulated, followed by Articles 58/a and 58/b, which provide for special character, the juvenile victim and the sexually abused victim or subject to trafficking. In these two cases, it is foreseen that the victim has some special rights related to her own special qualities.

Similarly, Article 59/a was added, which provides for the case of numerous victims of criminal offenses, in order to avoid delaying the process for this reason, guaranteeing their representation by the same counsel in cases where there is no impediment. Article 60 provides in detail the content of the request of the accusing victim, to enable the development of a normal judicial process. At the same time, it is foreseen that the civil lawsuit in the criminal process can be filed only by the victim or her inheritors.

\section{II.5- Prosecution and Judicial}

Regarding the prosecution role as a subject at the criminal proceedings the amendments are fundamental. For the first time, in the history of Albanian jurisprudence, from the post-communist period, the function of an independent, fully competent prosecutor is provided to exercise criminal prosecution according to his beliefs, convictions, so a decentralized function whose decisions on criminal prosecution cannot be contested or amended by an administrative hierarchy. Such decisions as they have been before that when the decision of a prosecutor at a lower court could be reviewed by a prosecutor at a higher court. According to these provisions, we hope that prosecutors with high integrity and professionally very capable will be included in the prosecution system. Because this decentralization, under the conditions of a corrupt prosecution as it is nowadays can violate the principles of justice. Thus, the powers of the prosecutor ${ }^{1}$ have been increased, for the first time, it is foreseen in terms of his rights to reach an agreement with the defendant and to propose it to the court, as well as to decide on the criminal order of punishment, these new institutes provided in the CPC (Article 24). Also, the competencies of the Special Prosecution Office in full compliance with the constitutional provisions, for justice reform have been foreseen, as well as the cases of conflict of competencies between this Special Prosecution and the ordinary prosecution have been regulated (Articles 28-29).

Deep and democratic amendments are foreseen in Chapter II of Part I of the Code, which mainly reflect the constitutional amendments on the jurisdiction of the courts, according to the justice reform. Specifically, Article 75/a has been reformulated in accordance with Article 135 of the revised Constitution and Articles 9 and 10 of the Law "On the Organization and Functioning of Institutions to Fight Corruption and Organized Crime", by providing the jurisdiction of the court against the crime of corruption for:

1 Palazzo, P. ( 2000) Lezioni di diritto penale comparato Torino, Giappichelli. p. 130-159. 
any subject who commits a criminal offense provided by Articles 244, 244/a, 245, 245/1, 257, 258, 259, 259/a, 260, 319, 319/a, 319/b, 319/c, 319/9, 319/d, 319/dh, $319 / \mathrm{e}$ (provisions in the field of corruption and organized crime);

any criminal offense committed by a structured criminal group, criminal organization, terrorist organization and armed band, that their definition is made in the provisions of the Criminal Code;

criminal charges against the President of the Republic, the Speaker of the Assembly, the Prime Minister, a member of the Council of Ministers, the judge of the Constitutional Court and the Supreme Court, the Attorney General, the High Inspector of Justice, the Mayor, the Member of Parliament, the Deputy Minister, the member of the High Judicial Council and the High Prosecution Council, and the heads of the central or independent institutions defined in the Constitution or by law;

any charges against the above former officials, for acts committed in the exercise of their duties;

According to the provisions of Article 75/b on the jurisdiction of the High Supreme Court are also reflected, the new constitutional amendments for justice reform in relation to this court, by keeping in its jurisdiction only the unification of judicial practice by the Criminal College and its amendment by its Colleges. Meanwhile, disputes over competencies are envisaged to be resolved by the Criminal College in the Advisory Chamber, as a competence that does not affect the function of this court and guarantees the same solution for the lower courts. The provisions provide for an amendment to the current rule on the jurisdiction of the Court against Corruption and Organized Crime, providing that in cases where one of the defendants is a minor, the proceedings against him shall be examined in each case by the relevant section of the ordinary court even though the subject matter jurisdiction may belong to the Court against Corruption and Organized Crime, the provision made in Article 80 of the CPC.

For the first time in the CPC, it is established the Court against Corruption and Organized Crime which is expected to review, at both levels, district court and appeal court, with a panel of three judges, because the selection of judges and their specialization guarantee the legislator's intention to a fair decision-making of the court. Hopefully, we expect that the establishment of this court will implement justice reform, so long awaited by all citizens. We believe that this court will give the green light to the entire justice system by turning it into an effective justice system and especially by fighting corruption among of judges and prosecutors, but as well as among the politicians in Albania.

By establishing the so call "Court of Corruption" we hope that Albania will not to be ranked at the first place on the list of countries with the highest corruption in the judiciary system. We hope that justice will be served to all Albanian citizens, so that 
they do not seek justice at the doors of the European Court ${ }^{1}$ just because of the dysfunction of the judicial system in Albania. Albanian citizens deserve access to justice, just like all European citizens.

Furthermore, an innovation foreseen by these amendments of the CPC are the provisions provided for the judicial police. The National Bureau of Investigation is established for the first time. This part is regulated based on the provisions of the amendments to the law on judicial police.

As we pointed out above, the position and role of the prosecutor ${ }^{2}$ in the preliminary investigation phase has undergone significant changes and remains a central and competent figure, during the preliminary investigation phase and the amendments are foreseen in harmony with the provisions of the new law on the prosecution, being provided for the manner of control of the actions performed by the prosecutor during the preliminary investigations and at their conclusion.

\section{Conclusions and Recommendations}

Regarding the amendments to the $\mathrm{CPC}$, we consider that they are very progressive as they are in harmony with international and European standards and some of them are defined for the first time in the Albanian jurisprudence. Defendant's rights letter constitutes a greater guarantee for the protection of the defendant's rights. It determines not only a right for the defendant but above all an obligation for the enforcements agencies to implement executing the rights. The sanctioning of the legal position of the victim in the criminal process and the accused victim is undoubtedly considered positive, as in all these years, despite its important and necessary role, it was not mentioned and specified the role of victims at all in the criminal procedure. The role of the victim in criminal proceedings has already been consolidated as a party in the process with all the rights in a regular criminal process.

Consolidation of provisions relating to the protection of witnesses, collaborator of justice and witnesses with a hidden identity. But comparing with international standards the approximation with them is still lacking, therefore it is recommended to be reformulated in the way that the identity of the protected or anonymous witness to not be disclosed for any reasons. Correspondingly, it is recommended that the provisions regarding the prohibited questions to be reformulated, so that the identity of the protected witness will not be disclosed.

\section{Bibliography:}

[1] Balla, R. (2017). Constitutional Reform, Criminal Justice Reform on Prevention of Organized Crime and Corruption, Proceedings of International Scientific Conference at Faculty of Law, Tirana University, Albania.

\footnotetext{
1 Pradel, J. \& Cortens, G. \& Vermeulen, G. \& Papialis, (2009). European Criminal Law. Tirane, Albania. p.155-209.

2 Dhrami, J. (2011). The Defendant and The Prosecutor. Tirane, Albania. p. 287-358.
} 
[2] Balla, R. (2007). Witness and Justice Collaborators Protection. The Journal " $E$ Drejta Parlamentare dhe Politikat Ligjore"“. Tirane, Albania. No 39.

[3] Cassese, A. (2003). International Criminal Law, Oxford University Press England.

[4] Dhrami, J. (2011). The Defendant and The Prosecutor. Tirane, Albania.

[5] Damaska, M. (1975). Structures of Authority and Comparative Criminal Procedure. Yale Law Journal, 84.

[6] Frase, Richard, S. (1995) German Criminal Justice as a Guide to American Law Reform, Weigend,: Similar Problems, Better Solutions?" USA Boston College International and Comparative Law Review, 18

[7] Islami, H. \& Hoxha, A. \& Panda, I. (2006) Proceedings Law. Morava, Tirane, Albania.

[8] Palazzo, P. \& Giappichelli. ( 2000) Lezioni di diritto penale comparato Torino, Italy.

[9] Pradel, J. \& Cortens, G. \& Vermeulen, G. \& Papialis, (2009). European Criminal Law. Tirane, Albania.

[10] Xhafo, J. (2010), International Criminal Law, Tirane, Albania.

[11] The report on the closure of the International Criminal Tribunal for the former Yugoslavia (ICTY) in the Closing of the Hague Tribunal, an International Criminal Tribunal for the former Yugoslavia in 1993, established by UN decision to try crimes in the former Yugoslavia, and the legacy it left behind.

[12] The Information published at Ministry of Justice web page On Amendments of the Criminal Proceedings Law. (March 2020).

[13] Vogler, R.. \& Ashgate, K.. ( 2005). A World View of Criminal Justice, London, England.

\section{Albanian Legal Acts}

[1] Constitutional Law Amendments (2016) published on Official Journal year 2016.

[2] Criminal Proceedings Code amended by law no. 36 date 30.03.2017, published on Official Journal year 2017.

[3] Law No. 97/2016 "On Organization and Functioning of Prosecution in the Republic of Albania", published on Official Journal no. 209, year 2016.

[4] Law on Organization and Functioning of Institutions to Fight Corruption and Organized Crime published on Official Journal no. 209, year 2016.

\section{European and International Legal Acts:}

[1] Directive 2012/29/EU Council of Europe October 2012 For the Determination of the Minimum Standards of Rights, Support and Protection of Victims of Crime, which replaced the Framework Decision of the Council Directive $2001 / 220 /$ JHA published in the Official Journal. 
[2] Framework Decision of the Council of Europe of 15 March 2001 on the Victims' Attitude in Criminal Procedure published on the European Official Journal.

[3] Resolution of the Council of Europe on Procedure for the Enforcement of Procedural Rights of Suspected or Accused Persons in Criminal Proceedings published on European official journal.

[4] Directive 2012/29 of the EU and the Council on October 2012 To set minimum standards for the rights, support and protection of victims of crime, which replaced the Council Framework Decision 2001/220.

[5] Directive 2012-13-EU, on the right to information in criminal proceedings published on European official journal.

[6] Directive 2013-48- EU on the right of access to a defense counsel in criminal proceedings published on European official journal.

[7] Directive 2010-64-EU, on the right to translation in criminal proceedings published on European official journal.

[8] Directive of the European Parliament and of the Council (2013) 821 "On the strengthening of certain aspects of the presumption of innocence and the right to be present at a trial in criminal proceedings".

[9] European Union Schengen Convention of year 1990.

\section{European Court Decisions:}

[1] ECtHR's Decision no. 4378/02 date March 10th 2009, Bykov vs Russia published on European official journal.

[2] ECtHR's Decision ABRAMYAN v. RUSSIA 10709/02 published on European official journal.

[3] ECtHR's Decision Pelissier dhe Sassi v. France, no. 25444/94 § 52, ECHR 199911, published on European official journal.

[4] ECtHR's Decision Mattocia vs Italy, no. 23989/94, § 58, ECtHR 2000-IX.

[5] ECtHR's Decision Ollinger v Austria, no. 42780/98 § 34, 20 Prill 2006, published on European Court.

[6] ECHR's Decision, Mineli vs Switzerland 25.3.1983.

[7] Sergey Zolotukhin v. Russia - HUDOC - Council of Europe.

[8] Internet web pages:

[9] -https://hudoc.echr.coe.int/eng\#\{\%22itemid\%22:[\%22001-58764\%22]\}, (March 20 th 2020).

[10]-https://hudoc.echr.coe.int/eng\#\{\%22itemid\%22:[\%22001-76098\%22]\}, (March 20th 2020).

[11] http://data.europa.eu/eli/dec_framë/2001/220/oj, (March 30th 2020).

[12] https://eurlex.europa.eu/search.html?qid=1585598884134\&text=Directive $\% 202012 / 29 \% 20 /$ EU\&scope=EURLEX\&type=quick\&lang=en $\left(\right.$ March $30^{\text {th }}$ 2020).

[13] https://hudoc.echr.coe.int/fre\#\{\%22itemid\%22:[\%22001-91704\%22]\}, (April 1st 2020). 
[14]-https://eur-lex.europa.eu/legalcontent/EN/TXT/?uri=CELEX\%3A42000A0922\%2802\%29, (March 16th 2020).

[15]-https://hudoc.echr.coe.int/eng\#\{\%22itemid\%22:[\%22001-57540\%22]\}

[16] https://ec.europa.eu/transparency/regdoc/?fuseaction=list\&coteId=1\&year $=2013 \&$ number $=821 \&$ version $=A L L \& l a n g u a g e=e n,\left(\right.$ April $\left.2^{\text {nd }} 2020\right)$.

[17] - hudoc.echr.coe.int > app > conversion > pdf; (March 16 th 2020)..

[18]-https://eur-lex.europa.eu/legalcontent/en/TXT/?uri=CELEX\%3A32012L0029, (April 2nd 2020).

[19]-https://eur-lex.europa.eu/legal-content/EN/TXT/?uri=celex:32012L0013, (March 20th 2020).

[20] https://eur-lex.europa.eu/legalcontent/EN/TXT/?uri=celex\%3A32013L0048, (March 20 th 2020).

[21]-https://eurlex.europa.eu/LexUriServ/LexUriServ.do?uri=0J:L:2010:280:0001:0007:en: PDF (March 20th 2020).

[22] https://eur-lex.europa.eu/legal content/EN/TXT/?uri=uriserv:OJ.C_.2009.295.01.0001.01.ENG\&toc=0J, [23] (March 20th 2020).

[24]-https://hudoc.echr.coe.int/fre\#\{\%22itemid\%22:[\%22001-155161\%22]\}, (March 20th 2020).

[25] https://hudoc.echr.coe.int/eng\#\{\%22itemid\%22:[\%22001-58226\%22]\}, (March 20 $0^{\text {th }} 2020$ ).

[26] https://www.trt.net.tr/shqip/ballkani/2017/12/12/koment-tribunali-ihages-dhe-trashegimia-qe-la-prapa-866543 (April 3rd 2020). 